\title{
TECHNICAL SOLUTIONS FOR LOADING AND UNLOADING OPERATIONS ON FREIGHT TRAINS ON AN ELECTRIFIED TRACK OF A LOGISTIC TERMINAL
}

DOI: $10.36724 / 2072-8735-2020-\mid 4-4-66-72$

\author{
Sergey P. Vakulenko, \\ Russian University of Transport, Moscow, Russia, \\ post-iuit@bk.ru \\ Airat M. Nasybullin, \\ Russian University of Transport, Moscow, Russia, \\ nasybullin.airat@mail.ru
}

\begin{abstract}
Keywords: accelerated cargo transportation, permanent freight train, high- yield cargo, freight operations on an electrified track, freight Express, multi-system locomotives, moveable catenary system
\end{abstract}

\begin{abstract}
The article describes the problem of ensuring the performance of cargo operations on the electrified receiving and sending route of a cargo terminal. The relevance of this article is determined by the need to provide new services in the field of freight transport and the lack of implementation of the described technological solutions on the railway infrastructure of the Russian Federation. The authors suggest ways to reduce the time spent on the road for a certain category of cargo by running freight trains of constant formation. The article also describes the main advantages of the proposed solutions, as well as constraints, which include the lack of possibility of carrying out loading and unloading operations with containers on the electrified path of the logistics terminal. The authors studied the foreign experience of applying technical and technological solutions to solve the described problem (in Germany, Japan and South Korea). The authors identify and describe the characteristic features of the proposed measures based on the theoretical research. The article describes several possible options for implementing measures taking into account various features, and also suggests two most likely options for equipping railway stations or using rolling stock. The article can be useful when choosing technical and technological solutions for the organization of accelerated railway freight transport on the railway infrastructure of the Russian Federation, taking into account the local characteristics of stations.
\end{abstract}

Information about authors:

Sergey P. Vakulenko, PhD in Technical Sciences, professor, Director of Institute of Management and Digital Technologies of the Russian University of Transport, Moscow, Russia

Airat M. Nasybullin, post-graduate student of the Russian University of transport, Moscow, Russia

\footnotetext{
Для цитирования:

Вакуленко С.П., Насыбуллин А.М. Технико-технологические решения для погрузо-выгрузочных работ с грузовыми поездами на электрифицированном пути логистического терминала // Т-Сomm: Телекоммуникации и транспорт. 2020. Том І4. №4. С. 66-72.

For citation:

Vakulenko S.P., Nasybullin A.M. (2020) Technical solutions for loading and unloading operations on freight trains on an electrified track of a logistic terminal. T-Comm, vol. 14, no.4, pp. 66-72. (in Russian)
} 
Existing trends in the Russian transport services market outline for railways the need to find new solutions for the transportation of highly profitable goods. Thus, in the period of 19912019 , the share of freight transportation by rail, in the total volume of traffic, does not show any growth. Increasingly, cargo owners and freight forwarding companies are choosing an alternative to rail transport, preferring road transport.

Constraining factors in the competition in the corridor of 400$1500 \mathrm{~km}$. are the speed of delivery, the complexity of the preparatory and initial and final operations, reliability, flexibility and complex of the transportation of goods.

In order to attract highly profitable goods to railway transport, researchers in the transport industry agree on the feasibility and effectiveness of organizing the movement of accelerated freight trains of constant formation with the opportunity of carrying out cargo operations at intermediate stations without changing the train layout $[1,4,5,6,7,9]$.

The main ideology in operating these trains is movement by agreed arrival and departure times, with unloading and loading of goods at the siding reception and departure track of "intermediate" stations (terminals) in combination with an accelerated reloading process.

The first mention of the effectiveness of the organization of such transportation was published in 1940 by V.V. Povorozhenko [4]. However, to date, the proposals have not been implemented.

To date, a number of technical and technological solutions to launch the transportation in question, with the exception of conceptual issues, have not been studied, developed or proposed. Due to the lack of such transportation in the Russian Federation, the possibility of loading and unloading operations with containers (and / or swap bodies) on the electrified path of the logistics terminal has not been widely studied.

In order to carry out rational loading and unloading operations, taking into account the high safety requirements when being on an electrified path, the authors of this paper consider the following solutions:

1) the use of sectional insulators on the contact network of the anchor type, with joint mechanical protection of the contact network from damage;

2) the use of an automatic tap-off contact bus;

3) refusal to use the contact network at the logistics terminal (train arrival by inertia, due to distributed traction, etc.).

\section{Application of sectional insulators of the contact wire with mechanical protection of the contact wire}

At first glance, a rational solution to ensure safe loading and unloading operations on the electrified path of the logistics terminal is to de-energize the contact network.

Moreover, the complete de-energization of the contact network of the anchor type involves additional time costs associated with fixing the train-set, which is not effective in conditions of accelerating the transportation process.

In this regard, in order to eliminate the need to fix the trainset, it is proposed (within the cargo front) to allocate a special section of the contact network with insulated sectional insulators.

Partitioning will ensure the allocation of a section of the track for a powered locomotive and a de-energized section of the cargo front to comply with safety conditions when performing cargo operations.
Figure 1 shows a conceptual diagram of the partitioning of a contact network.

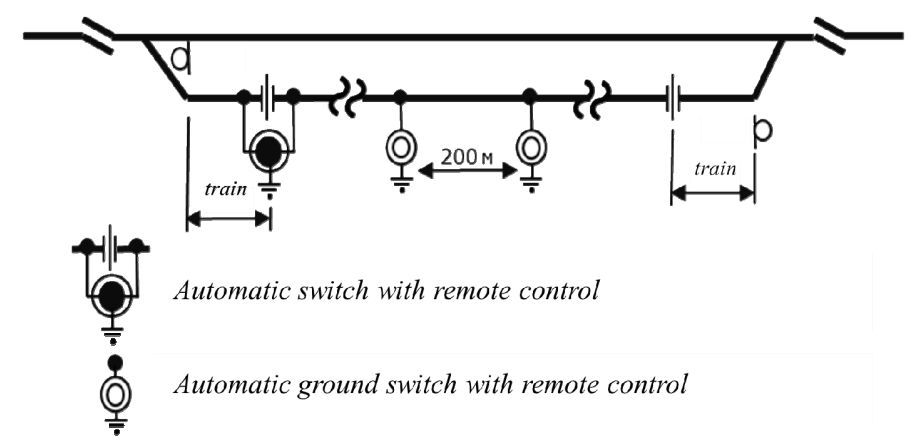

Figure 1. Conceptual scheme of contact wire of a cargo front

When implementing the proposed measures, the likelihood of electric shock to personnel is reduced, however, significant concerns remain regarding damage to the contact network, including supports.

In turn, to ensure guaranteed protection of the supports and the contact network, it is proposed to use mechanical protection of the parts under consideration. For protection, it is proposed to use a specialized console, which can be located in the area of the upper outline of the approximation of buildings. The console should be located along the entire length of the loading and unloading track of the cargo front.

In order to eliminate the additional load on the supports of the contact network, the protective console is proposed to be mounted on independent supports. In this case, the console parts must be equipped with insulators or insulating material.

In addition, in order to exclude the collision of equipment on the car during loading and unloading operations or when using the loading and unloading track to carry out operations with other freight trains, it is proposed to use specialized barriers in the area of the lower outline of the approximation of buildings.

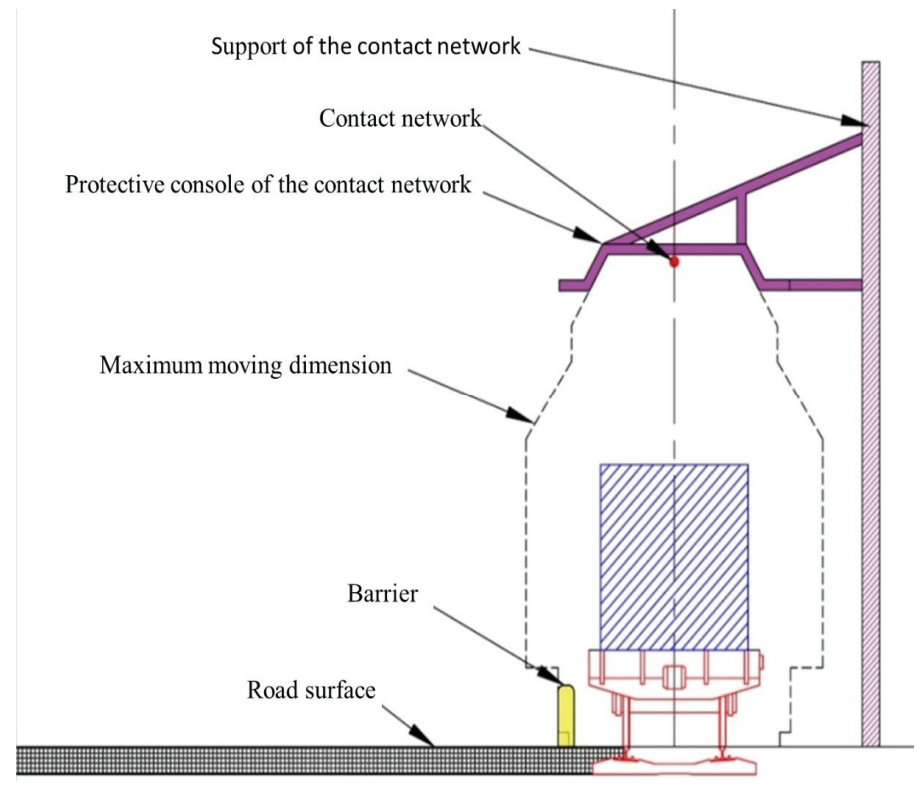

Figure 2. Shows an offered scheme of protecting mechanical protection of the contact wire and wagon 
As can be seen from Figure 2, the use of this technical equipment reduces the variability of the use of loading and unloading machines (hereinafter referred to as LUM).

The most suitable means of mechanization are a forklift (Fig. 3a) or a specialized material handler designed to stack containers in a row (Fig. 3b).

However, the use of a forklift truck requires the presence of container "pockets" for their capture, which limits the scope of use of forklifts

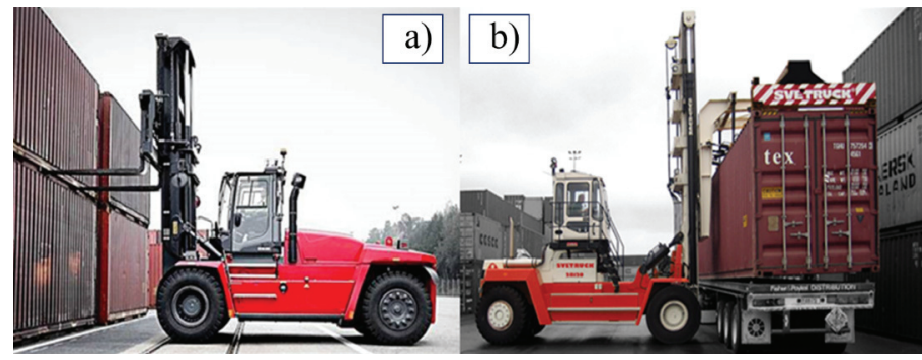

Figure 3. Forklift and container stacker

In order to minimize the influence of the human factor, to ensure integrated security, it is proposed to equip LUM with special devices that, if necessary, will programmatically set a limit on their actions.

Among the foreign experience in the implementation of cargo operations under a contact wire of the anchor type, it is worth highlighting the South Korean experience (Fig. 4).

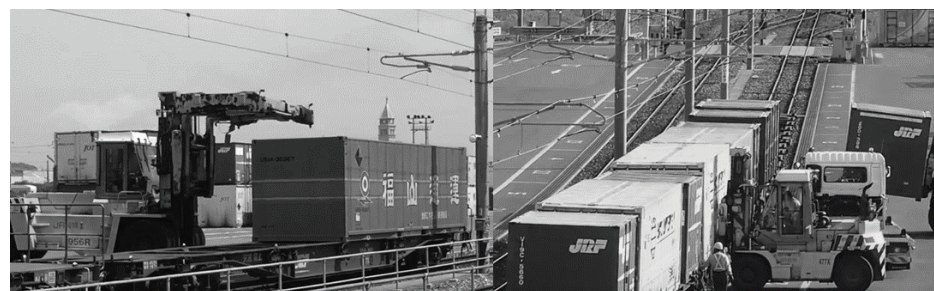

Figure 4. An example of freight operations on the electrified anchor track, South Korea

As Figure 4 shows, freight operations are carried out without mechanical protection of the contact wire.

The application of the Korean experience in Russia is rather limited due to high safety requirements.

\section{Tap-off bus contact wire}

In this option, instead of the classic anchor contact wire on the loading and unloading tracks, it is proposed to use a current collection system with an automatic tap-off bus.

Structurally, the contact bypass busbar trunking is a hard contact rail, which is equipped with special rods with traction drives and rotating clamps to ensure automatic folding and unfolding (Fig. 5). In turn, the contact rail is a set of copper or aluminum tires enclosed in an extruded aluminum casing.

A drop contact bus will allow rolling stock to approach the loading and unloading track in its working position with its own traction, and in the allotted position, it will provide space for the universal LUM to work.

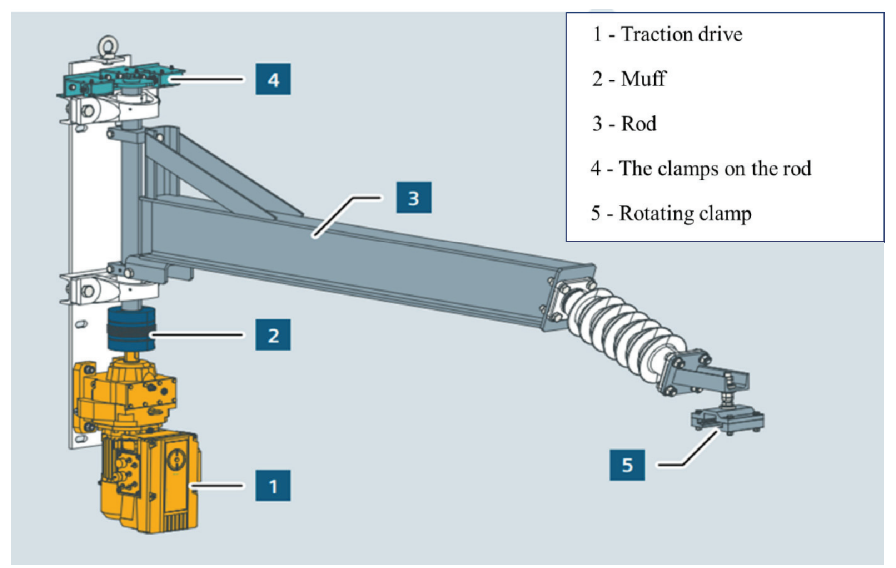

Figure 5. The scheme of rotating rod of busbar

During cargo operations, for electric power consumption for the locomotive's own needs and for the train's needs, the current collector should be located on a specialized non-tap section, so the entire branch busbar system should have a specialized section from the anchor contact wire to the rigid branch contact bus system.

Figure 6 shows a diagram of the location of rolling stock on a loading and unloading track equipped with a bypass contact busbar.

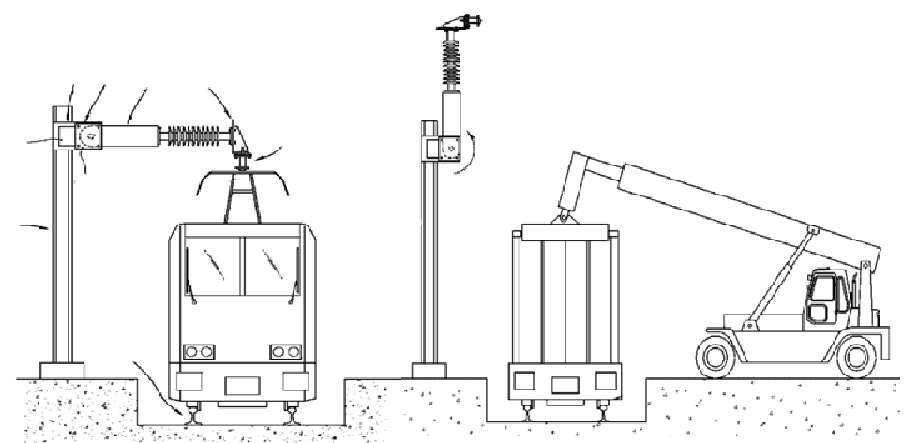

Figure 6. Locating rolling stock on a loading and unloading track equipped with a bypass contact busbar

As foreign experience of using such a busbar, test container terminals in South Korea can be mentioned. [11] (figure. 7).
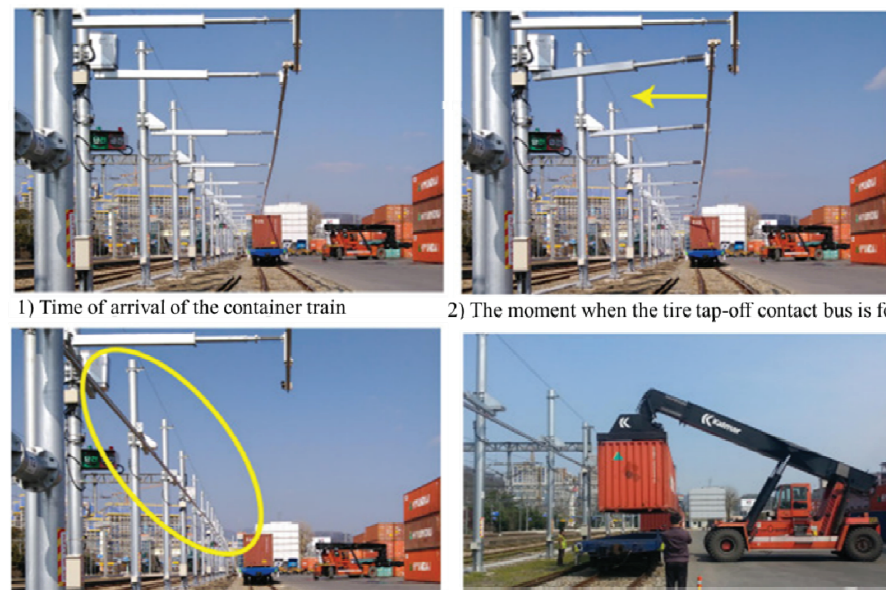

The moment when the tire tap-off contact bus is folding

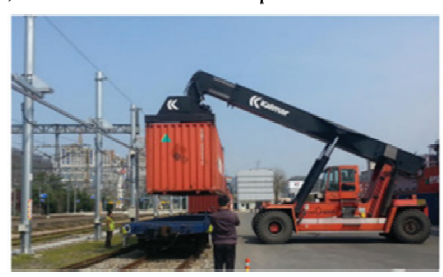

4) Time when cargo operations are performed

bus is ending folding

Figure 7. Using busbar at Okcheon terminal, South Korea 
On the territory of the Russian Federation, a bypass wire is actively used in motorcar depots for servicing high-speed and high-speed electric trains (depot Podmoskovnaya and Metallostroy) [2].

The devices of tap-off contact busbars are used to reduce costs and time for shunting operations with locomotives, as well as to provide safe access to the roof equipment of the trains. Thanks to the bypass contact wire, the arrival and departure from the depot of electric trains are carried out on their own.

It should be noted that despite providing optimal operating conditions for the loading and unloading front, the drop contact bus system is characterized by the difficult operation, including the need to ensure operation in climatic conditions with high temperature extremes.

\section{Refusal from using contact wire}

In order to solve the problem the research also considers partial or full refusal to use the contact wire.

\subsection{Partial refusal from using contact wire}

Partial refusal implies the absence of a contact network within the boundaries of the useful length of the cargo front. The use of such solutions is relevant if it is necessary to ensure the possibility of the arrival of a container train driven by an electric locomotive to the existing high-performance terminal, including one equipped with a gantry crane. It is understood that in order to provide electric power to the electric locomotive and train composition, the locomotive parking lot will be equipped with a contact network section.

Within partial refusal, two options for the arrival of a train on a loading and unloading track are considered.

Option 1

Arrival of the train using electric rolling stock in the area where there is no contact network is carried out with the current collectors lowered, while the train will be provided due to the accumulated kinetic energy.

Figure 8 shows a schematic diagram of the movement of a container train on the freight front with a partial refusal from the contact network.

After tracing the area free of the contact network, the current collectors rise, further braking or departure from this track is provided in normal mode.

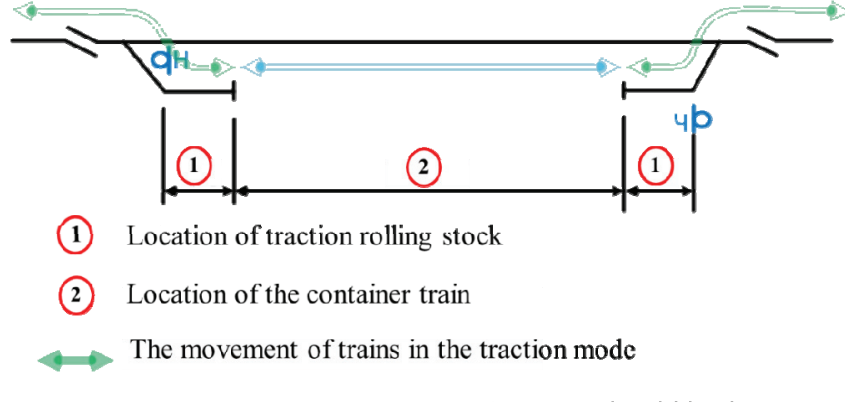

Figure 8. Schematic diagram of the movement of a container train on the freight front with a partial refusal from the contact network
When applying similar equipment and technology on the territory of the Russian Federation, it must be taken into account that the section and the speed of movement with the current collectors lowered should be justified on the basis of:

- raction and brake calculations;

- rrival standards for prohibiting indications of the exit / route traffic light;

- Inaccurate / inconsistent control by the driver of the train brakes;

- the possible premature operation of the brakes in connection with incorrect or inaccurate actions of the locomotive driver.

- $\mathrm{c}$ ngestion at the station due to the premature operation of the auto brakes.

In the event of a possible premature operation of the autobrakes of a train within a section free of the contact network, the loading and unloading front should have devices and equipment for withdrawing the train from this section.

As an example of equipment, it is proposed along the cargo front to provide a flexible or rigid trolley bus line that will connect to an electric locomotive and provide power for the output of the train at low speed.

As an example of the partial refusal to use the contact network when container trains arrive due to the accumulated kinetic energy, we can note the experience used at the container terminal "DUSS-Terminal München-Riem", located in the suburbs of Munich (Germany).

Figure 9 shows the DUSS-Terminal München-Riem container terminal.

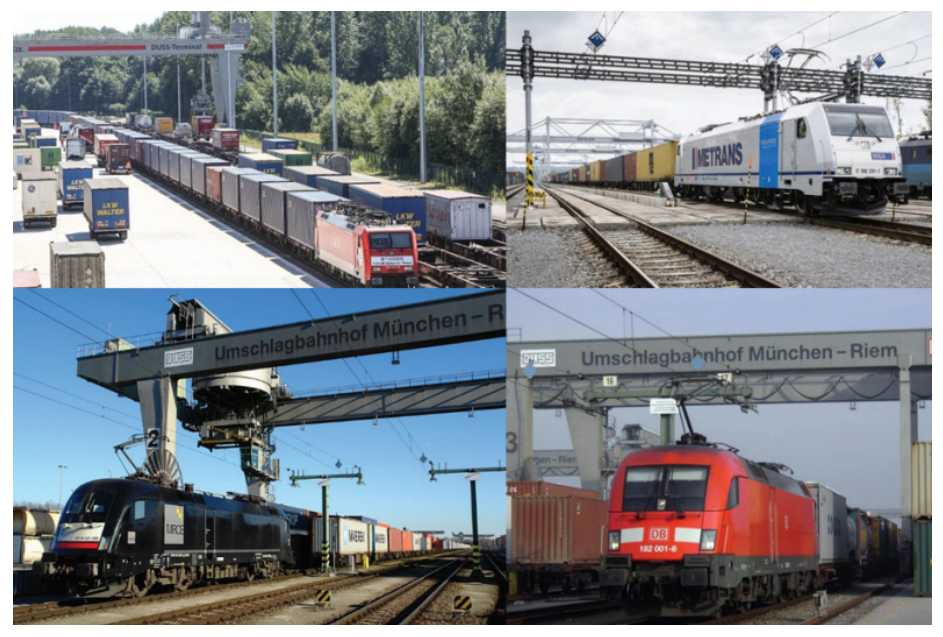

Figure 9. An example of the partial refusal to use the contact network, terminal "DUSS-Terminal München-Riem"

This option, similar to the first one, provides for the absence of a contact network within the useful front length.

At the same time, to ensure the acceptance of the train on the track under consideration, it is proposed to use distributed traction at the train-set - the "pull-push" system. In other words, in the composition of a freight train of constant formation at its both ends there will be one section of the locomotive.

Arrival of the train on the track will be carried out by powering the tail section of the locomotive, and departure from the loading and unloading track will be provided by powering the head section. 
To power the train, during the period of cargo operations, sections of the locomotive must be located on sections of the track equipped with a contact network. At the same time, to fulfill the conditions for locomotives to be located under the contact network section, the length of the train must satisfy the useful length of the loading and unloading track.

Figure 10 shows a conceptual diagram of the formation of a container train driven by two sections of an electric locomotive at both ends of the train.

When locating electric locomotives at the ends of the train, it is necessary to provide modularity for controlling sections from a leading locomotive. Due to the distribution of traction, modularity will ensure the elimination of strong longitudinal compressive forces during acceleration and braking, thereby reducing the load on couplers and car frames, the best use of regenerative braking (due to the distribution of traction forces in the train-set), as well as accelerating the work of classical friction (pneumatic) braking by creating an "air wave" from both ends of the train [3].

In the case of non-synchronous operation of locomotives, it is worth noting that it is necessary to carry out calculations and conduct tests with verification of extrusion of light empty flatcars in curves, as well as when operating exclusively the tail section.

At the same time, it is necessary to develop a special technology for driving full-load freight trains (57 and 71 conventional wagons) with distributed traction by electric locomotives.

To ensure the movement of trains without changing locomotives at the points of docking of the genera of currents, the technical characteristics of an electric locomotive should provide movement along sections of railways with both alternating and direct currents.

An example of the locomotive under consideration are the Russian experimental two-system electric locomotive 2EV120 or the passenger electric locomotive EP20, as well as the design electric locomotive 2ES20.

The closest example of the implementation of such traction on the territory of the Russian Federation are electric trains ED1 and ED4DK, driven at both ends of the train by two sections of an electric locomotive VL80s or VL10 [8].

As the foreign experience in operating such trains with distributed traction, one can single out the experience used in Japan - the contain $\mathrm{r}$ train of the M250 series (Figure 11), used for domestic transportation of large and medium-tonnage containers [12].

\subsection{Total refusal from using contact wire}

This option implies the complete absence of a contact network, both within the boundaries of the useful length of the cargo front, and in the area where the locomotive stops.

With a complete refusal to use the contact network, it is proposed to use multisystem traction rolling stock.

Multisystem traction rolling stock is a rolling stock, the technical characteristics of which are able to provide transportation both on electrified (with various kinds of current), and on nonelectrified railway lines. For continuous operation on nonelectrified lines, locomotives must be equipped with a dieselgenerator module (hereinafter - DGM).

The use of multisystem rolling stock will completely eliminate the need for electrification of the loading and unloading front, unambiguously solve a number of problems related to ensuring safety during loading and unloading operations, in addition, it will allow operating the locomotive in non-electrified areas without disconnecting it.

Among foreign multisystem traction rolling stocks, the locomotive of the German manufacturer Siemens, the Vectron Dual Mode locomotive [10], deserves special attention.

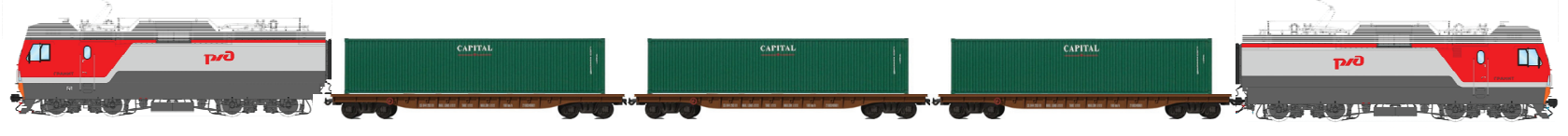

Figure 10. Diagram of the formation of a container train driven by two sections of an electric locomotive at both ends of the train

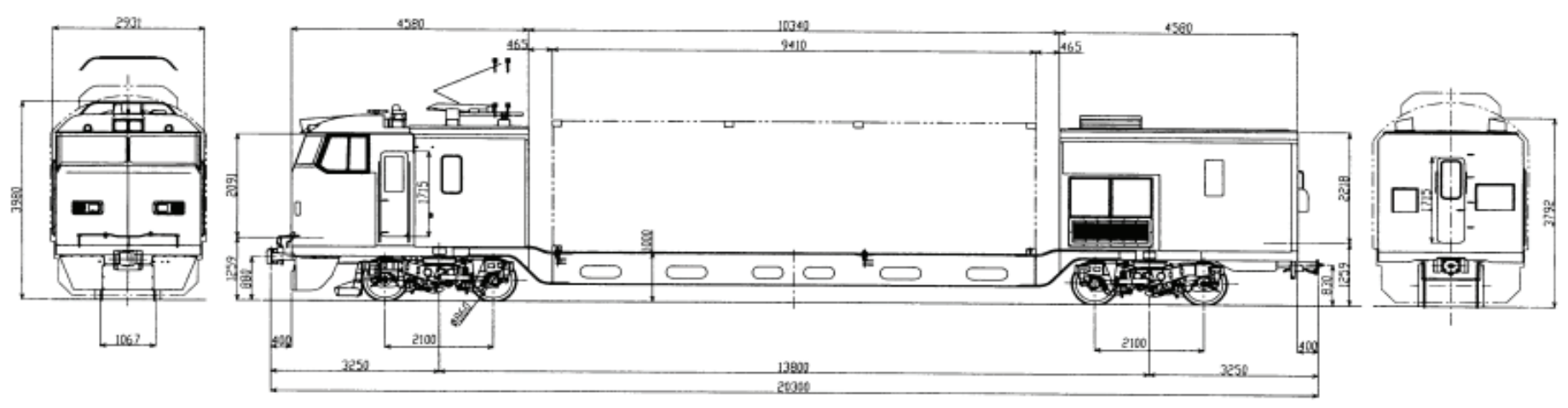

Figure 11. A scheme of a car of a distributed-traction container train 
A locomotive designed for light rail freight transport, the electrical equipment of which provides operation on lines with alternating current $15 \mathrm{kV}$ with a frequency of $16.7 \mathrm{~Hz}$. with a design speed of up to $160 \mathrm{~km} / \mathrm{h}$. The locomotive is equipped with a $2000 \mathrm{~kW}$ diesel generator set. The stock of diesel fuel is 2500 liters. The manufacturer declares that the operation of the locomotive in the DGM mode is positioned as a "hybrid locomotive"

The manufacturer has set the operational ability to use $80 \%$ of the route in the electric locomotive mode and $20 \%$ in the diesel locomotive mode.

An example of such rolling stock on the railway network of the Russian Federation is the experimental multi-system locomotive 2EV120 "Prince Vladimir". The locomotive consists of two four-axle sections, each section, in addition to the main devices allowing to run on alternating $25 \mathrm{kV}$ and direct current $3 \mathrm{kV}$, $50 \mathrm{~Hz}$, is equipped with a compact DGM with a capacity of up to $500 \mathrm{~kW}$.

The 2EV120 locomotive was designed on the basis of the "multisystem" locomotive TRAXX AC3 ("Bombardier Inc."), with the "Last Mile" functional option, which has proven itself on European railways. In Europe, the "Last Mile" functional option is used for shunting operations for the formation and disbanding of trains, as well as for supplying groups of cars for loading and unloading operations, where the maintenance of a separate shunting locomotive is neither expedient nor efficient.

\section{Conclusion}

To ensure the conditions for combining the processes of loading and unloading and powering the electric locomotive, it is necessary to use one of the proposed technical solutions: a bypass bus for the contact wire, the use of sectional insulators and the refusal from the contact wire in the loading and unloading area.

The use of sectional insulators with a joint protective console is characterized by metal consumption and installation difficulty, while, due to the peculiarities of cargo operations, it limits the scope of application of highly specialized loading and unloading equipment.

The most preferred option of equipping the station, allowing loading and unloading without disbanding the structure, is a section free of the contact network (DUSS-Terminal MünchenRiem - as an example of the implementation of such an event). It is worth noting that this option requires lower capital and operating costs compared to others.

However, based on the local conditions of the stations where it is impossible to for the train to proceed along a section free of the contact network under the influence of kinetic energy, they can be equipped with a drop-wire system for the contact wire. Moreover, the rationality of equipping the station should be economically and technologically justified.

In the transition to a new legal model for the implementation of the project, providing for the ownership of both traction and non-traction rolling stock as a single owner, it makes sense to use multisystem traction rolling stock or distributed rolling stock ("push-pull"), which allows you to solve the full range of issues related to the provision of loading and unloading on electrified railway lines.

In all cases, it is necessary to perform additional technical and economic calculations when deciding on the appropriateness of the solutions considered.

\section{Referenses}

1. Vakulenko S.P., Kolin A.V. \& Prokofiev M.N. (2014). Novaya tekhnologiya uskorennyh gruzovyh perevozok zheleznodorozhnym transportom [New technology for accelerated freight transport by rail]. Transport Rossijskoj Federacii - Transport of the Russian Federation, no. 2, pp. 20-25. (in Russian)

2. Denisov YU.A., Yanchenko E.G. \& Shevchenko M.A. (2009). Depo «Metallostroy» [Railway depot «Metallostroy»]. Vestnik instituta problem estestvennyh monopolij: Tekhnika zheleznyh dorog - Bulletin of the Institute of problems of natural monopolies: railway Engineering, no.3 (7), pp. 82-89. (in Russian)

3. Zajcev, A.A., Troickij P.S. (2019) Motorvagonnye gruzovye elektropoezda - al'ternativa lokomotivnoj tyage. Sravnenie i analiz [Electric freight trains are an alternative to locomotive traction. Comparison and analysis]. Mir transporta - World of Transport and Transportation. Vol. 17, no.3, pp. 72-81. (in Russian)

4. Povorozhenko, V.V. (1940) Organizaciya gruzovoj raboty promezhutochnyh stancij $i$ dvizheniya sbornyh poezdov [Organization of cargo operation of intermediate stations and movement of combined trains]. Moscow: Transzheldorizdat.

5. Prokofiev M.N. (2018). Sovershenstvovanie tekhnologii uskorennyh gruzovyh perevozok zheleznodorozhnym transportom [Improving the technology of accelerated freight transport by rail] Candidate's thesis, Moscow. (In Russsian)

6. Prokofiev M.N. (2010) Marshrutnaya set' uskorennyh perevozok [Route Network of Rapid Freight Traffic]. Mir transporta World of Transport and Transportation, no. 5, pp. 78-83. (in Russian)

7. Kolin A.V., Kotov V.A. (2008) Vozmozhnosti skorostnoj perevozki gruzov [Features of high-speed cargo transportation]. Zheleznodorozhnyj transport - Railway transport, no. 3, pp. 20-23. (in Russian)

8. Leshchev A.I., Koshkina N.V. \& Soltus K.P (1999) Elektropoezd ED1 s lokomotivnoj tyagoj. Problemy razvitiya rel'sovogo transporta [Electric train ED1 with locomotive traction. Problems of rail transport development]. IX Mezhdunarodnaya nauchno-tekhnicheskaya konferenciya - IX International scientific and technical conference. Thesis of reports, pp. 38-39. Crimea, Alushta. (in Russian)

9. Kolin A.V. (2008) Skorostnye gruzoperevozki [High-speed cargo transportation]. Gazeta «Gudok» - Newspaper «Gudok», Issue 12.02.2008. Retrieved from http://www.gudok.ru/newspaper/?ID= 717214. (in Russian)

10. (2019) Kompaniya Siemens predstavila lokomotiv Vectron s kombinirovannym privodom [Siemens introduced the Vectron locomotive with a combined drive] Retrieved from http://www.zdmira.com/news/kompaniasiemenspredstavilalokomotiv vectronskombinirovannymprivodom. (in Russian)

11. Soon-Dal, ParkSeong-Cheol \& KimSang-Woon Byun (2017) The world's first domestic development of movable rigid catenary system for container yards. Jornal of Korean society for urban Railway, Vol.5. No.4, pp. 1045-1051.

12. Asakura K., Nakagawa T. (2005) Development of Series M 250 Freight Electric Multiple - Unit. Journal - Institute of Electrical Engineers of Japan, No. 125, pp. 288-291. 


\section{ТЕХНИКО-ТЕХНОЛОГИЧЕСКИЕ РЕШЕНИЯ ДЛЯ ПОГРУЗО-ВЫГРУЗОЧНЫХ РАБОТ С ГРУЗОВЫМИ ПОЕЗДАМИ НА ЭЛЕКТРИФИЦИРОВАННОМ ПУТИ ЛОГИСТИЧЕСКОГО ТЕРМИНАЛА}

Вакуленко Сергей Петрович, Российский университет mрансnорта (МИИТ), Москва, post-iuit@bk.ru Насыбуллин Айрат Марсович, Российский университет трансnорта (МИИТ), Москва, nasybullin.airat@mail.ru

\section{Аннотация}

Рассматривается проблема обеспечения выполнения грузовых операций на электрифицированном приемо-отправочном пути грузового терминала. Актуальность данной статьи определяется необходимостью предоставления новых услуг в сфере грузовых перевозок и отсутствием внедрения описанных технологических решений на железнодорожной инфраструктуре Российской Федерации. Авторы предлагают способы сокращения времени нахождения в пути для определенной категории грузов за счет движения грузовых поездов постоянной формирования. В статье описаны основные преимущества предлагаемых решений, а также ограничения, к которым относится отсутствие возможности проведения погрузочноразгрузочных работ с контейнерами на электрифицированном пути логистического терминала. Авторы изучили зарубежный опыт применения технических и технологических решений для решения описанной проблемы (в Германии, Японии и Южной Корее). Авторы выявляют и описывают характерные особенности предлагаемых мероприятий на основе теоретических исследований. В статье описываются несколько возможных вариантов реализации с учетом различных особенностей, а также предлагаются два наиболее вероятных варианта оснащения железнодорожных станций или использования подвижного состава. Статья может быть полезна при выборе технико-технологических решений для организации ускоренных железнодорожных грузовых перевозок на железнодорожной инфраструктуре Российской Федерации с учетом местных условий станций.

Ключевые слова: ускоренная перевозка грузов, грузовой поезд постоянного формирования, высокодоходные грузы, грузовые операции на электрифицированном пути, грузовой экспресс, мультисистемные локомотивы, отводная контактная шина.

\section{Литература}

І. Вакуленко С.П., Колин А.В., Прокофьев М.Н. Новая технология ускоренных грузовых перевозок железнодорожным транспортом // Транспорт РФ. 20I4. № 2 (5I). С. 20-25.

2. Денисов Ю.А., Янченко Е.Г., Шевченко М.А. Депо "Металлострой" // Вестник института проблем естественных монополий: Техника железных дорог. №3 (7) август 2009 г.

3. Зайцев А.А., Троицкий П.С. Моторвагонные грузовые электропоезда - альтернатива локомотивной тяге. Сравнение и анализ // Мир транспорта, том 17. № 3. 2019. С. 72-81.

4. Повороженко В.В. Организация грузовой работы промежуточных станций и движения сборных поездов // Москва 1940.168 с.

5. Прокофьев М.Н. Совершенствование технологии ускоренных грузовых перевозок железнодорожным транспортом / Дисс. канд. техн. наук. М.: РУТ(МИИТ). 2018. $182 \mathrm{c.}$

6. Прокофьев М.Н. Маршрутная сеть ускоренных перевозок // Мир транспорта. № 5. 20I0. С. 78-83.

7. Колин А.В., Котов В.А. Возможности скоростной перевозки грузов // Железнодорожный транспорт №3. 2008. С. 20-23.

8. Лешев А.И., Кошкина Н.В., Солтус К.П. Электропоезд ЭДІ с локомотивной тягой. Проблемы развития рельсового транспорта // IX Международная научно-техническая конференция. Тезисы докладов. Крым, Алушта. 1999. С. 38-39.

9. Колин А.В. Скоростные грузоперевозки [Электронный ресурс] // Газета Гудок. - Режим доступа: http://www.gudok.ru/newspaper/?ID= 7|72।4.

10. Компания Siemens представила локомотив Vectron с комбинированным приводом [Электронный ресурс] // Официальный сайт журнала "Железные дороги мира" - Режим доступа: http://www.zdmira.com/news/ kompaniasiemenspredstavilalokomotivvectronskombinirovannymprivodom.

II. Soon-Dal, ParkSeong-Cheol, KimSang-Woon Byun. The world's first domestic development of movable rigid catenary system for container yards // Jornal of Korean society for urban Railway, vol. 5. No 4. 2017, pp. I045-105I.

12. Asakura K., Nakagawa T. Development of Series M 250 Freight Electric Multiple - Unit // Journal - Institute of Electrical Engineers of Japan № /25. 2005, pp. 288-291.

Информация об авторах:

Вакуленко Сергей Петрович, профессор, к.т.н., Директор Института управления и иифровых технологий Российского университета транспорта (МИИТ), Москва, Россия

Насыбуллин Айрат Марсович, аспирант Российского университета транспорта (МИИТ), Москва, Россия 